\title{
ZEYTİN (Olea europaea L.) YAPRAĞININ FONKSİYONEL ÖZELLİKLERİ VE GIDALARDA KULLANIM POTANSIYYELİ
}

\author{
Mehmet Ali Salık, Songül Çakmakçı* \\ Atatürk Üniversitesi, Ziraat Fakültesi, Gıda Mühendisliği Bölümü, Erzurum, Türkiye
}

Geliş / Received: 12.10.2021; Kabul / Accepted: 30.11.2021; Online bask1 / Published online: 15.12.2021

Salık, M. A., Çakmakçı, S. (2021). Zeytin (Olea europaea L.) yaprağının fonksiyonel özellikleri ve gıdalarda kullanım potansiyeli. GIDA (2021) 46 (6) 1481-1493 doi: 10.15237/gida.GD21133

Salık, M. A., Cakmakç, S. (2021). Functional properties and usage potentials in food of olive (Olea europaea L.) leaf. GIDA (2021) 46 (6) 1481-1493 doi: 10.15237/gida.GD21133

\section{ÖZ}

Tıbbi-aromatik bitkiler, koruyucu ve tedavi edici özelliklerinden dolayı yüzyllardır kullanılmaktadır. Bunların fitokimyasal profillerinin belirlenmesi, kullanım alanlarının ve endüstriyel potansiyellerinin geliştirilmesi üzerine yapılan çalışmalara ilgi gittikçe artmaktadır. Bu bitkilerden biri de zeytin yaprağıdır. Zeytin yaprağı; Avrupa ve Akdeniz ülkelerinde (Türkiye, Yunanistan, İspanya, İtalya, Fransa, İsrail, Fas ve Tunus) halk hekimliğinde yaygın olarak kullanılmaktadır. İnsan beslenmesinde ekstrakt, bitki çayı ve toz olarak kullanılabilen zeytin yaprağ1; antioksidan bileşikler, fenolikler, flavonoitler, sekoiridoitler (oleuropein), triterpenler ve karatenoitler gibi biyoaktif bileşenler açısından zengindir. Zeytin yaprağı, bileşimindeki oleuropein ve fenolik bileşiklerden dolayı antioksidan, antimikrobiyel, anti-inflamatuar, antiaterojenik, antikarsinojenik, antiviral, hipoglisemik ve nöroprotektif gibi farmakolojik etkiler göstermektedir. Biyoaktif bileşikler açısından potansiyel olan ve fitokimyasal profilleri belirlenmiş bitkisel kaynaklar ve tarımsal gıda ve yan ürünleri sağlığı korumak için nutrasötiklerin ve fonksiyonel gıdaların geliştirilmesinde ümit verici görünmektedir. Bu derlemede, zeytin yaprağının fitokimyasal profiline dikkat çekerek, sağlık faydaları ve gida sanayiinde kullanım potansiyeli ele alınmıştr.

Anahtar kelimeler: Zeytin yaprağı, terapötik etki, gıda, sağlık

\section{FUNCTIONAL PROPERTIES AND USAGE POTENTIALS IN FOOD OF OLIVE (Olea europaea L.) LEAF}

\begin{abstract}
Medicinal-aromatic plants have been used for centuries due to their protective and therapeutic properties. There is an increasing interest in studies on the determination of their phytochemical profiles, the development of their usage areas, and industrial potential. One of these plants is the olive leaf. Olive leaf is widely used in folk medicine in European and Mediterranean countries (Turkey, Greece, Spain, Italy, France, Israel, Morocco, and Tunisia). Olive leaf, which can be used as an extract, herbal tea, and powder in human nutrition; is rich in bioactive components such as antioxidant compounds, phenolics, flavonoids, secoiridoids (oleuropein), triterpenes, and carotenoids. Olive leaf has pharmacological effects such as antioxidant, antimicrobial, antiinflammatory, antiatherogenic, anticarcinogenic, antiviral, hypoglycemic, and neuroprotective due to
\end{abstract}

\footnotetext{
*Yazışmalardan sorumlu yazar / Corresponding author;

$\triangle$ cakmakci@atauni.edu.tr $\quad$ (+90) 4422312491

圆:(+90) 4422315878
}

Mehmet Ali Salık; ORCID no: 0000-0003-4727-9830

Songül Çakmakçı; ORCID no: 0000-0003-0334-5621 
the oleuropein and phenolic compounds in its composition. Plant sources and agri-food wastes and by-products with potential for bioactive compounds and proven phytochemical profiles are promising in the development of nutraceuticals and functional foods to protect health. In this review, the health benefits and use in the food industry are discussed by drawing attention to the phytochemical profile of olive leaf.

Keywords: Olive leaf, therapeutic effect, food, health

\section{GİRİ̧}

T1bbi ve aromatik bitkilerin ham bitki özlerinin gıda, ilaç ve parfümeri gibi alanlarda Antik çağlardan beri kullanıldığı (Ekren vd., 2013), günümüzde de önemli potansiyel uygulamalara sahip bu bitkilere olan talebin yılda \%15-25 arttı̆ 1 belirtilmektedir (Thakur ve Kumar, 2021). Dünya Sağlık Örgütü (WHO) tarafindan, tıbbi bitkilerin tedavi edici ve besleyici özellikleri nedeniyle tüketiciler tarafindan yaygın olarak kullanıldığı, dolayısıyla tıbbi bitki ürünlerine yapılan harcamaların gittikçe arttığı belirtilmektedir (Kiani vd., 2016; Thakur ve Kumar, 2021). Tibbi ve aromatik bitki pazarının yılda yaklaşık 14 milyar ABD Doları olduğu ve 2050 yılına kadar 5 trilyon ABD Dolarından fazla olacağ1 tahmin edilmektedir. Dünya çapında yaklaşık 3000 tıbbi ve aromatik bitki türünün ticareti yapılmakta, bunların 2000 türü İsviçre, Almanya ve Fransa gibi Avrupa ülkelerine ait olup (Thakur ve Kumar, 2021), Hindistan da 7000 tubbi ve aromatik bitki türü ile önemli bir konumdadır (Prasathkumar vd., 2021).

Gelişmiş ülkelerin $\% 60$ 'ından fazlası, gelişmekte olan ülkelerin ise $\% 80 ' i$ şifalı bitkilere; kültürel olarak daha kolay kabul edilmeleri, insan vücudu ile uyumlu olmaları ve olumsuz etkilerinin düşük olması nedeniyle, birinci basamak sağlık hizmetlerinde güvenmektedir (Prasathkumar vd., 2021; Thakur ve Kumar, 2021). WHO'ya göre, çeşitli tıbbi uygulamalar için 21 bin tıbbi bitki kullanılmaktadır. Hindistan'da, temel hastalıkları tedavi etmek için yaklaşı 2500 bitki türünün kullanıldı̆ı̆, Dünyanın farklı bölgelerinde tıbbi uygulamalarda kullanilan 100'den fazla bitki türünün Hindistan'a ait olduğu bildirilmektedir (Prasathkumar vd., 2021). Türkiye'de ise 11700'den fazla bitki türü (yaklaşık \%30'u endemik) olup (Güler vd., 2021), bunların 500 kadarı tıbbi amaçlı kullanılmaktadır (Polat, 2019).
Tibbi ve aromatik bitkiler genellikle orman ağaçları, süs bitkileri, baharatlar ve çeșniler içinde yer almaktadır (Gahukar, 2018). Bitkilerin yaprak ve çiçek gibi kısımları fitokimyasalların ana kaynağını oluştururken; meyve, tohum, gövde, kök ve sap gibi kısımları yardımcı kaynak olarak kabul edilir. Bitki metabolitleri primer ve sekonder olmak üzere iki şekilde sinıflandırılmaktadır. Her canlı hücrede bulunan ve büyüme/gelişmede rol alan primer metabolitler içerisinde aminoasitler, proteinler, şekerler, nükleik asitler ve polisakkaritler yer almaktadır. Sekonder metabolitler ise primer metabolitlerden türetilmekte olup, çeşitli biyolojik etkilere sahip büyüme ve gelişmede etkili olmayan moleküllerden oluşmaktadır. Sekonder bitki metabolitleri terpenoitler, alkaloitler ve fenolikler olmak üzere üç tipte sinıflandırılır. Terpenoitler 40000'den fazla bileşik içeren en büyük bitki metabolitleri sınıfı olup fenolikler yaklaşık 8000 bileşik içermektedir (Prasathkumar vd., 2021). Biyoaktif bileşikler bakımından zengin bitkiler, çeşitli farmakolojik özelliklerinden dolayı bazı sağlık sorunlarına (tüberküloz, kanser, şeker hastalı̆̆1, kalp hastalıkları, yara iyileşmesi, astım, farenjit ve hipertansiyon gibi) çare olarak siklıkla kullanılmaktadır (Lubbe ve Verpoorte, 2011; Prasathkumar vd., 2021). Günümüzde önemli bir küresel sorun olan Korona virüs salginıla mücadelede de insanların geleneksel tubba ve bitkisel tedaviye yönelimlerinin arttığ1 görülmektedir (Kadığlu ve Kadıŏlu, 2021).

Tibbi ve aromatik bitkilerden elde edilen ekstraklar, uçucu yağlar, renk maddeleri vb. ürünler çeşitli endüstriyel ürünlerin (bitkisel sağlık ürünleri, ilaç, kozmetik, kişisel bakım ürünleri, bitki koruma ürünleri, gida takviye ürünleri vb.) üretiminde hammadde olarak kullanılmaktadır (Lubbe ve Verpoorte, 2011). Bu nedenle, nutrasötikler ve fonksiyonel gida ürünlerine ilgi gün geçtikçe artmakta ve bu ilgi yapılan araştırma konularına da yansımaktadır. Fonksiyonel gidalar, 
araştırmacılar ve gıda endüstrisi için önemli bir odak noktası haline gelmiştir. Tüketiciler, genellikle doğal kaynaklardan elde edilen bileşenlerin kullanıldığı fonksiyonel gidaları tercih etme eğilimindedir (Gahukar, 2018). Bu durum, biyoaktif bileşikler açısından potansiyel olan ve fitokimyasal profilleri kanıtlanmış bitkisel kaynaklar (tıbbi ve aromatik bitkiler, baharatlar, otlar vb.) ve tarımsal gıda yan ürünleri (yaprak, tohum, sap, kabuk, posa vb.) sağlığ1 korumak için nutrasötiklerin ve fonksiyonel gidaların geliştirilmesinde ümit verici görünmektedir. $\mathrm{Bu}$ derlemede, tarımsal atık durumunda olan zeytin yaprağının fitokimyasal profiline dikkat çekilerek, sağlık faydaları ve gida sanayiinde kullanım/kullanılabilme potansiyelleri hakkında genel bilgiler verilmiştir.

\section{ZEYTİN YAPRAĞININ ÖZELLİKLERİ Biyoaktif Özellikler}

Zeytin ağac1 (Olea europaea L.), 25 cins ve 600 türden oluşan Oleaceae familyasina ait yaprak dökmeyen bir bitki olup (Arslan vd., 2021), birçok Akdeniz ülkesinde (İspanya, İtalya, Yunanistan, Türkiye, Tunus, Portekiz, Suriye, Fas ve Cezayir) yaygın olarak yetişmektedir (El ve Karakaya, 2009; Blasi vd., 2016; Arslan vd., 2021). Dünyada 2019 yllında yaklaşık 10 milyon hektar alanda (hA) 20 milyon ton zeytin üretimi yapılmıştır (FAO, 2019). Türkiye yaklaşık 880 bin hA üzerinde 1.5 milyon ton zeytin üretimi ile dünya üretiminin yaklaşık \%14'ünü karşılamaktadır (FAO, 2019; TÜİK, 2019). Zeytinin farklı kısımları (meyve, yağ ve yaprak) beslenme ve tıbbi amaçlarla kullanılmaktadır (El ve Karakaya, 2009; Blasi vd., 2016). Zeytin yapraklar1, zeytin meyvelerinin hasadı ve zeytin ağacinın budanması (toplam ağırlığının yaklaşı \%25'ini oluşturmakta) sırasında veya zeytin meyvesinin yağa işlenmesi öncesindeki temizleme ve ayıklama işlemleri sırasında açığa çıkan (toplam zeytin ağırlı̆̆ının yaklaşık \%10'unu oluşturmakta) tarımsal ve endüstriyel bir yan üründür (Rahmanian vd., 2015; Markhali vd., 2020; Arslan vd., 2021). Bir hektar alandaki zeytin ağaçlarının budanması sonucunda; yaklaşık olarak 1500 ton yaprak ve küçük dallardan oluşan budama atıklarından \%25'ini yapraklar oluşturmakta ve $375 \mathrm{~kg}$ zeytin yaprağ otaya ç1kmaktadır (Espeso vd., 2021). Bu ortalama veriler dikkate alındığında, Türkiye'de bir yılda yaklaşık 880 bin hA'da yaklaşık 1.3 milyon ton budama atığı elde edilmekte ve bunların yaklaşık 330 bin tonunu zeytin yaprağının oluşturduğu tahmin edilmektedir. Zeytinin, zeytinyağına işlenmesi sırasında meydana gelen \% $\% 10^{\prime} l u k$ yaprak atığ1 da hesaplamaya dâhil edildiğinde 330 bin tonun üzerinde bir atık potansiyelinin olacağ1 ortadadır. Bu tahmini verilerden de anlaşılacağı üzere zeytin yaprakları, yüksek katma değerli ürünlerin üretiminde kullanılabilecek nitelikte, potansiyel ve ucuz hammadde kaynağını oluşturmaktadır. Konunun önemi nedeniyle gerekli girişimlerin yapılması; hem çevre kirliliğinin önlenmesi, hem de zeytin yaprağının kullanım alanlarının artırılması ve endüstriyel potansiyellerinin geliştirilmesi bakımından Ülkemiz ve Dünya ekonomisine büyük katk1 sağlayacaktır.

Zeytinyağı işleme sırasında açığa çıkan atıklar ve yan ürünler (kara su, posa, çekirdek, yaprak vb.) biyoaktif bileşenler bakımından önemli potansiyel kaynakları oluşturmaktadır. Zeytin yaprakları kimyasal bileşimi ve biyoaktif özellikleri bakımından katma değeri yüksek ürünlerin geliştirilmesinde kullanılabilecek ucuz bir hammaddedir (Nunes vd., 2016). Zeytin yaprağının kimyasal bileşimi ve biyoaktif özellikleri; zeytin çeşidi, iklim koşulları, ağaç yaşı, tarımsal uygulamalar, genetik, sicaklık ve ekstraksiyon prosedürleri gibi faktörlere bağl1 olarak değişebilmektedir (El ve Karakaya, 2009; Rahmanian vd., 2015; Blasi vd., 2016). Zeytin yapraklarının biyoaktif bileşikleri arasında sekoiridoitler (oleuropein, ligstroside, dimethyloleuropein ve oleoside), flavonoitler (apigenin, kaempferol, luteolin), fenolik bileşikler (kafeik asit, tirozol, hidroksitirosol) (Rahmanian vd., 2015; Markhali vd., 2020), karotenoitler, tokoferoller ve klorofil bulunmaktadır (Souilem vd., 2017; Tarchoune vd., 2019; Markhali vd., 2020). Oleuropein; zeytin meyveleri, yaprakları ve tohumlarında en bol bulunan, kolayca ekstrakte edilebilen ve zeytin ürünlerinde karakteristik acilığ1 veren fenolik bir bileşiktir (Blasi vd., 2016; Nicoli vd., 2019). Zeytin yaprağ1 kimyasal bileşimiyle de dikkat çekmekte; ortalama olarak \%46.24-49.75 su, \%37.14-42.58 karbonhidrat, 
\%5.04-7.61 protein, \%1.05-1.30 yăg ve \%2.864.45 kül içermektedir (Boudhrioua vd., 2009). Karbonhidratlardan; glukoz, fruktoz, miyoinositol, galaktoz, galaktinol, sükroz, rafinoz, stakioz ve nişasta fraksiyonları, minerallerden ise potasyum, manganez, magnezyum ve bakır fazla miktarda bulunmaktadır (Souilem vd., 2017).

Zeytin yaprağının antioksidan aktivitesinin, fenolik profilinin ve biyoaktif özelliklerinin belirlenmesi üzerine yapılmış çok sayıda araştırma mevcuttur. Bazıları aşağıda özetlenmiştir: Sevim ve Tuncay (2012), Ayvalık ve memecik zeytin yapraklarında; toplam fenolik madde miktarını (TPC) 230.64-237.73 mg kafeik asit eşdeğeri (KAE)/100 g, DPPH (1,1-diphenyl-2picyrlhydrazyl) antioksidan aktiviteyi 1214.51$2027.64 \mu$ mol troloks eşdeğeri (TE) $/ 100 \mathrm{~g}$, ABTS (2,2'-azino-bis (3-ethylbenzothiazoline-6-sulfonic acid)) antioksidan aktiviteyi 825.38-1056.16 $\mu \mathrm{mol}$ TE/100 g olarak tespit etmişlerdir. Blasi vd. (2016), farklı İtalyan zeytin yapraklarında; TPC miktarını 40.9-66.6 $\mathrm{mg}$ gallik asit eşdeğeri (GAE)/g, DPPH antioksidan aktiviteyi \%40.986.1, ABTS antioksidan aktiviteyi 44.8-99.8 $\mathrm{mg}$ TE/g, oleuropein miktarın1 4.30-91.8 mg/g olarak bulmuşlardır. Başka bir çalışmada ise zeytin yapraklarında; TPC 219.85-464.27 mg GAE/100g kuru ağırlık, toplam flavonoit madde miktarı (TFC) 98.4-377.06 mg kateşin eşdeğeri (CE)/100g ekstrakt, DPPH antioksidan aktivite $\% 58.75-98.2$, ABTS antioksidan aktivite \%97.7398.65 olarak saptanmıştır. Ayrıca bu örneklerde 18 adet fenolik asit tanımlanmış olup, en fazla saptanan üç fenolik asit şunlardır: oleuropein (11.38-25.08 mg/100 g kuru ağırlık), kumarik asit (0.05-32.24 mg/100 $\mathrm{g}$ kuru ağırlık) ve vanilik asit (1.28-11.0 mg/100 g kuru ağırlık) (Brahmi vd., 2013). Nicoli vd. (2019), 15 farklı İtalyan çeşidi zeytin yapraklarında oleuropein miktarı ile TPC, $\mathrm{DPPH}$, ORAC ve süperoksit anyon süpürme antioksidan sonuçlarını sırasıyla; 7-30 g/ kg kuru ağılık, 11-49 g GAE/kg, 8.67-29.89 $\mu \mathrm{mol} \mathrm{TE} / \mathrm{g}$ kuru ağırlık, 0.81-4.25 $\mu \mathrm{mol} \mathrm{TE} / \mathrm{g}$ kuru ağılık, 27.66-48.92 $\mu \mathrm{mol} \mathrm{TE} / \mathrm{g}$ kuru ağırlık olarak belirlemişlerdir. Başka bir araştırmada, zeytin yaprağında kafeik asit (220.5 $\mathrm{mg} / \mathrm{kg})$, verbascoside $(966.1 \mathrm{mg} / \mathrm{kg})$, oleuropein $(26471.4$ $\mathrm{mg} / \mathrm{kg}$ ), luteoli 7-O-glikozit (4208.9 mg/kg), rutin
(495.9 mg/kg), apigenin 7-O-glikozit (2333.1 $\mathrm{mg} / \mathrm{kg}$ ) ve luteolin 4'-O-glikozit $(1355.9 \mathrm{mg} / \mathrm{kg}$ ) olmak üzere 7 farklı fenolik bileşik tanımlanarak miktarları saptanmıştır (Pereira vd., 2007). Salah vd. (2012), zeytin yaprağında oleuropein miktarı ile TPC, TFC ve DPPH antioksidan aktivite değerlerini sirasıyla; $30.76-57.24 \mathrm{mg} / \mathrm{g}$, 73.05144.19, mg GAE/g, 56.75-125.64 mg CE/g ve 7.90-18.64 $\mathrm{IC}_{50}(\mu \mathrm{g} / \mathrm{mL})$ olarak tespit etmişlerdir. Tarchoune vd. (2019) tarafindan zeytin yaprağında; TPC 62.84-67.91 mg GAE/g, TFC 5.85-13.61 mg CE/g, ABTS antioksidan aktivite 69.05-113.84 $\mu \mathrm{mol} \mathrm{TE} / \mathrm{g}, \alpha$-tokoferol miktar1 10.12-82.37 $\mu \mathrm{g} / \mathrm{g}$, klorofil miktar1 506.08-829.29 $\mu \mathrm{g} / \mathrm{g}$ ve karotenoit miktarı $26.90-44.33 \mu \mathrm{g} / \mathrm{g}$ kuru ağırlık olarak bulunmuştur. Aynı araştırmada 13 adet de fenolik bileşik (oleuropein, protokateşik asit, vanilik asit, ferulik asit, hidroksitirosol ve tirozol ana bileşikler olmak üzere) tanımlanmıştır.

\section{Terapötik Özellikler ve Klinik Çalışmalar}

Epidemiyolojik çalışmalar, düzenli olarak meyve, sebze ve kabuklu yemiş tüketimi ile sağlıklı bir yaşam arasında belirgin bir pozitif ilişkinin olduğunu göstermektedir (Carvalho vd., 2010). $\mathrm{Bu}$ nedenle hem geleneksel hem de modern tipta önemli bir yere sahip olan şifalı bitkiler, sahip oldukları fitokimyasal bileşikler sayesinde pek çok hastalığın tedavisinde fayda sağlamaktadır/ kullanılmaktadır (Prasathkumar vd., 2021).

Tarımsal yan ürünlerden olan zeytin yaprağı; tıbbi ve aromatik bitki olma özelliğiyle dikkat çeken, halk hekimliğinde çeşitli hastalıkların tedavisinde kullanım potansiyeline sahip olan ve yapilan araştırmalar ile fitokimyasal profili belirlenmiş önemli bir kaynaktır. Zeytin yaprağına ait terapötik özellikler (Şekil 1) ile epidemiyolojik çalısmalar sonucunda elde edilen bazı klinik bulgular aşağıda özet olarak sunulmuştur.

Zeytin yaprağının (kuru ve infüzyon olarak ağızdan alındığında) halk hekimliğinde; mide ve bağırsak hastalıkları, ağız temizleyici, ishal, idrar yolu enfeksiyonları, hipertansiyon ve bronşiyal astım gibi rahatsızlıkların tedavisinde kullanıldığ1 bilinmektedir (Uylaşer ve Yıldız, 2014; Özcan ve Matthäus, 2017). Zeytin yaprağının tedavi edici özellikleri bileşiminde bulunan fitokimyasallardan 
kaynaklanmaktadır (Özcan ve Matthäus, 2017). Zeytin yaprağında yapılan araştırmalar sonucunda belirlenen terapötik özellikler Şekil 1'de gösterilmiştir. Buna göre, zeytin yaprağının antioksidan, antimikrobiyel, anti-inflamatuar, antiaterojenik, antikarsinojenik, antiviral, hipoglisemik ve nöroprotektif gibi pek çok terapötik etkiye sahip olduğu görülmektedir (Khan vd., 2007; El ve Karakaya, 2009; Rahmanian vd., 2015; Özcan ve Matthäus, 2017; Nicoli vd., 2019; Romani vd., 2019).

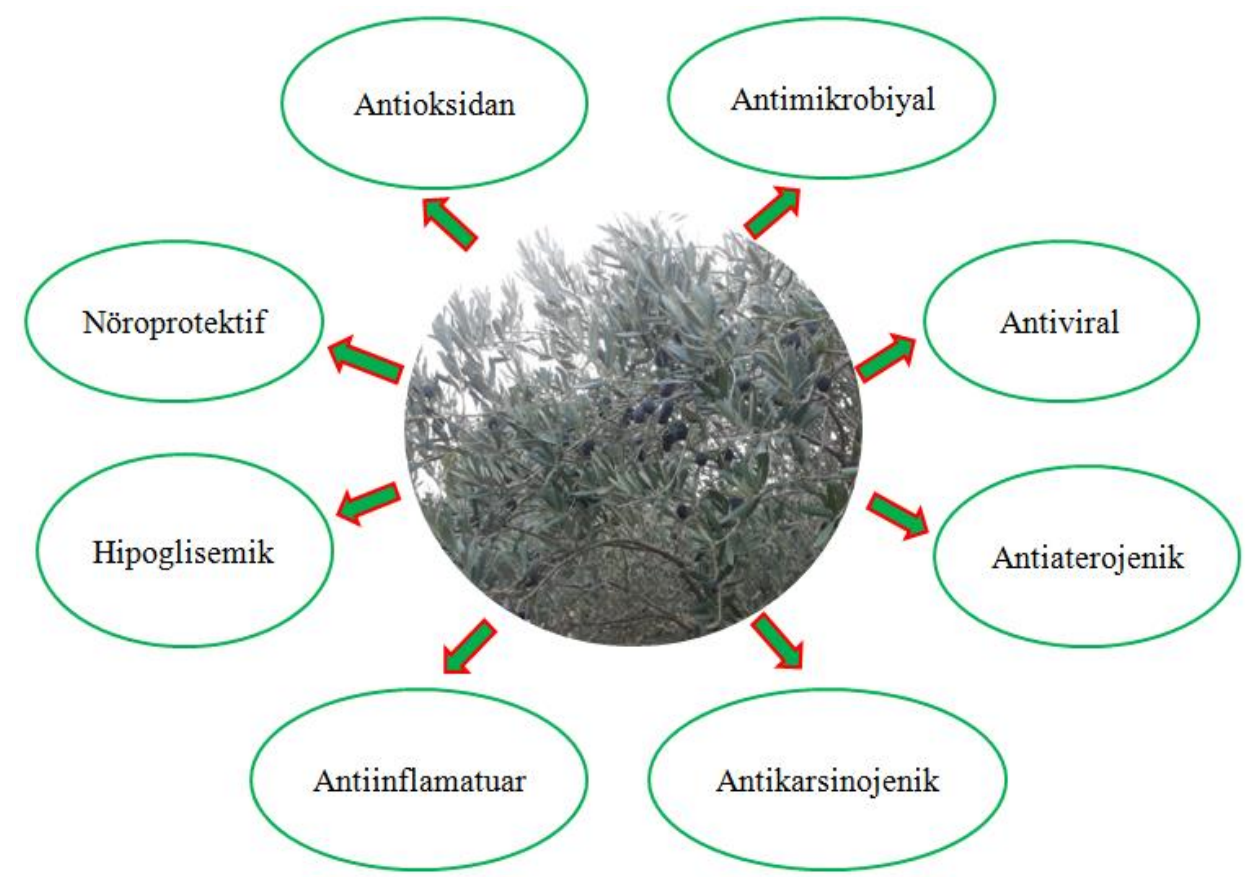

Şekil 1. Zeytin yaprağının terapötik özellikleri (Khan vd., 2007; El ve Karakaya, 2009; Rahmanian vd., 2015; Özcan ve Matthäus, 2017; Nicoli vd., 2019; Romani vd., 2019; Markhali vd., 2020) (Antiİnflamatuar: İltihap ve ödem giderici, Antiaterojenik: Deride oluşan şişlikleri ve kızarıklıkları giderici, Hipoglisemik: Kan şekeri düşürücü, Nöroprotektif: Nöron/sinir hücresi koruyucu)

Perrinjaquet-Moccetti vd. (2008), zeytin yaprağ1 ekstraktının (ZYE) insanlarda takviye edici gida olarak kullanımı üzerine yapmış oldukları araştırmada; ikizlerden oluşan bir grup insana 8 hafta boyunca günde iki kez olmak üzere $500 \mathrm{mg}$ veya $1000 \mathrm{mg}$ ZYE takviyesi uygulamışlardır. Araştırma sonucunda; $1000 \mathrm{mg}$ ZYE takviyesinin kan basıncını düşürdüğü, her iki konsantrasyon ZYE takviyesinin lipit profili üzerinde yararlı etkiler göstererek, plazma LDL, toplam-kolesterol ve trigliserit düzeylerini düşürdüğü tespit edilmiştir. Böylece yapılan araştırma, insanlarda ZYE'nin antihipertansif ve kolesterol düşürücü etkilerini doğrulamıştır.

Jemai vd. (2009), zeytin yaprağından elde edilen oleuropein ve hidroksitirozol ekstraktının Wistar fareleri üzerinde antidiyabetik ve antioksidan etkilerini araştırmışlardır. Bu amaçla, 4 hafta boyunca diyabetik farelere 8 ve $16 \mathrm{mg} / \mathrm{kg}$ vücut ağırllğ1 olacak şekilde oleuropein ve hidroksitirozol ekstraktı verilmiştir. Araştırma sonucunda her iki dozun da hipoglisemik ve hipolipidemik etkiler sergilediği, lipit peroksidasyon sürecini azalttığ ve antioksidan savunma sistemini geliştirdiği tespit edilmiştir. $\mathrm{Bu}$ sonuçlar, diyabet gibi oksidatif strese bağlı metabolik hastalıkların sıklı̆ının azaltılmasında potansiyel antioksidan kaynağı olarak zeytin ağac1 yan ürünlerinin önemini bir kez daha ortaya koymuştur.

Susalit vd. (2011), Evre-1 hipertansiyonu olan hastalarda tedavi amaçlı kullanılan kaptopril 
(anjiyotensin dönüştürücü bir enzim inhibitörü) yerine, ZYE kullanım olanaklarını araştırmışlardır. $\mathrm{Bu}$ amaçla, hastalara 8 hafta boyunca günde iki kez $500 \mathrm{mg}$ ZYE ile $12.5 \mathrm{mg}$ (ilk iki hafta) ve 25 mg (son altı hafta) kaptopril ağızdan verilmiştir. Araştırma sonucunda günde iki kez $500 \mathrm{mg}$ (toplamda $1000 \mathrm{mg}$ ) ZYE verildiğinde; Evre-1 hipertansiyonlu hastalarda sistolik (büyük tansiyon) ve diyastolik (küçük tansiyon) kan basınçları ile kan trigliserit düzeyini etkili bir şekilde düşürdüğü tespit edilmiştir. Sonuç olarak, ZYE'nin kan basıncını düşürme etkisi kaptopril ile benzer bulunmuş olup, günde $1000 \mathrm{mg}$ ZYE'nin karaciğer ve böbrek fonksiyonlanını etkilemeden ağızdan alınmasının güvenli ve tolere edilebilir olduğu görülmüştür.

Wainstein vd. (2012), diyabetik insanlarda ve farelerde hipoglisemik bir ajan olarak ZYE'nin etkisini araştırmışlardır. Bu amaçla, Tip-2 diyabetli hastalara 14 hafta boyunca günde bir kez ağızdan $500 \mathrm{mg}$ ZYE verilmiştir. Araştırma sonucunda, ZYE ile tedavinin diyabetli hastalarda glukoz homeostazını normalleştirdiği belirlenmiştir. Hayvan deneylerinde ise ZYE'nin nișasta sindirimini ve emilimini azalttı̆̆ belirlenmiş ancak bu durum istatistiksel olarak önemli bulunmamıștır. Benzer şekilde yapılan başka bir araştırmada ise orta yaşlı fazla kilolu erkeklerde insülin duyarlllığ1 üzerine zeytin yaprağ polifenollerinin etkisi araştırılmıştır. Bu amaçla, deneklere 12 hafta boyunca günde bir kez $51.1 \mathrm{mg}$ oleuropein ve $9.7 \mathrm{mg}$ hidroksitirosol oral olarak verilmiștir. Araștırma sonucunda, zeytin yaprağ polifenolleri ile yapilan takviyenin, metabolik sendrom geliştirme riski taşıyan aşırı kilolu orta yaşlı erkeklerde insülin duyarlılığını ve pankreas $\beta$ hücresi salgilama kapasitesini önemli ölçüde iyileştirdiği saptanmıştır (de Bock vd., 2013).

Papachristodoulou vd. (2016), oleuropein'nin PC3 prostat kanseri hücreleri ile Doksorubisin (DXR)'in (kanser tedavisinde kullanılan güçlü bir antrasiklin antibiyotik) toksik etkisi üzerine etkisini araştırmışlar ve sonuçta oleuropein'nin, prostat kanseri hücrelerinin çoğalmasını önlediğini ve DXR'nin sitotoksik (hücreyi öldüren ya da fonksiyonunu durduran) dozunu önemli ölçüde azalttığını tespit etmişlerdir.
Gür vd. (2020), ZYE'nin diyabetik fareler üzerine olan antidiyabetik ve antioksidatif etkilerini araştırmışlardır. $\mathrm{Bu}$ amaçla, farelere 14 gün boyunca 0.25 ve $0.50 \mathrm{mg} / \mathrm{kg}$ ZYE ağızdan verilmiştir. Araştırma sonucunda; uygulama sonrasinda her iki dozun da alanin transaminaz (ALT), aspartat transaminaz (AST) ve alkalen fosfataz (ALP) düzeylerini düşürdüğü tespit edilmiştir. Yapılan in-vivo analizler, ZYE'nin oksidatif stresin kisitlanmasi ve antioksidan aktivitelerin güçlendirilmesi sayesinde antidiyabetik etkiye sahip olabileceğini göstermiştir.

Ruzzolini vd. (2018), oleuropein'in insan BRAF Melanom (bir çeșit cilt kanseri) hücreleri üzerindeki antikanser etkisini araştırmışlardır. Araştırma sonucunda, oleuropein'in A375 insan melanom hücreleri üzerinde kemoterapötiklerin sitotoksik etkisini artırdığ tespit edilmiştir.

Sudjana vd. (2009), ZYE'nin Campylobacter jejuni, Helicobacter pylori ve Staphylococcus aureus'a karș1 antimikrobiyel etki gösterdiğini belirlemișlerdir. Başka bir araştırmada ise ZYE'nin Bacillus cereus, Bacillus subtilis, S. aureus (Gram +), Escherichia coli, Pseudomonas aeruginosa, Klebsiella pneumoniae (Gram -) bakterileri ile Candida albicans ve Cryptococcus neoformans mantar türlerine karş1 antimikrobiyel etki gösterdiği saptanmışır (Pereira vd., 2007). Kolcuoğlu ve Halkman (2021) da ZYE'nin E. coli O157:H7, Salmonella enteritidis, E. coli biyotip-1, Listeria monocytogenes ve $S$. aureus (en yüksek inhibisyon bu türde belirlenmiş) patojenlerine karşı antimikrobiyel etki gösterdiğini belirlemişlerdir.

\section{Toksisite}

Çeşitli araștırmalarda, tıbbi bitkiler ve bitki kaynaklı ürünlerin modern sentetik ilaçlara göre insan vücudu için daha güvenli ve daha az zararlı olduğu öne sürülmektedir. $\mathrm{Bu}$ nedenle, şifalı bitkilerin tarih boyunca tüm dünyada, çeşitli hastalıkların geleneksel tedavisinde uzun süredir kullanıldığ1 bilinmekte olsa da, bitkilerin ve bitkisel kaynaklı sentetik ilaçların olumsuz etkileri göz ardı edilmemelidir (Ravanbakhsh vd., 2016). Yapılan literatür araștırması sonucunda; zeytin yaprağının veya bu yapraklardaki karakteristik bileşiklerin (oleuropein ve hidroksitirosol gibi) 
doğrudan insan ve hayvan deneklerinde toksikolojik olarak değerlendirilmesi üzerine yapilmış çalışmaların çok sinırlı olduğu görülmüştür. Ancak, bu bitkilerin bazı terapötik özelliklerinin araştırıldı̆̆ı çalışmalarda, zeytin yaprağının; tedavi edici özelliklerinin olduğu, karaciğer ve böbrekte her hangi bir toksik etki oluşturmadığ1 ve hatta bu organların fonksiyonlarını iyileştirdiği bildirilmektedir (Susalit vd., 2011).

Yapılan bir çalışmada, oleuropein'in farelerde letal dozunun $\left(\mathrm{LD}_{50}\right)$, ağızdan uygulama sonrasinın (3000 mg/ $\mathrm{kg}$ ), vücuda enjeksiyondan sonrasina $(1000 \mathrm{mg} / \mathrm{kg})$ göre daha fazla olduğu bildirilmiştir (Markhali vd., 2020). Farelerde subkronik toksisite üzerine $\% 35$ oranında hidroksitirosol içeren zeytin ekstraktının (H35) etkisinin araştırıldığ 1 bir araştırmada ise 90 gün boyunca farelere 125,250 ve $500 \mathrm{mg} / \mathrm{kg}$ vücut ağırlı̆ 1 olacak şekilde H35 uygulanmıştır. Araştırma sonucunda gözlenen en düşük yan etki düzeyi (LOAEL) ve gözlenmeyen yan etki düzeyi (NOEL) sirasiyla $500 \mathrm{mg} / \mathrm{kg}$ ve $250 \mathrm{mg} / \mathrm{kg}$ vücut ağırlığı olarak saptanmıştır (Heilman vd., 2015).

\section{Gıdalarda Kullanım Potansiyeli}

Son zamanlarda yapılan çalışmalarda; gıda kaynaklarını artırmak, fonksiyonel yeni gida ürünleri geliştirmek, sentetik gida katk1 maddelerine alternatif doğal kaynaklar bulmak ve atık sorunlarını çözmek gibi amaçlarla biyoaktif bileşikler açısından potansiyel olan tarımsal gida ve yan ürünleri ile gida işleme yan ürünleri ve atıklarının yaygın bir şekilde araştırma konusu olduğu görülmüştür (Nunes vd., 2016; Romani vd., 2019; Markhali vd., 2020). Bu bağlamda, fitokimyasal profili belirlenmiş ve tarımsal atık durumunda olan zeytin yaprağı önemli bir potansiyel olup kozmetik (parfüm, kolonya, krem, sabun, şampuan vb.) ve ilaç endüstrilerinde yaygın bir kullanım alanına sahip görünmektedir.
Geleneksel olarak; zeytin yapraklarının (taze, kuru veya infüzyon çay şeklinde) daha çok çeşitli hastalıkların tedavisinde tıbbi amaçlarla kullanıldığ1 bilinmektedir (Özcan ve Matthäus, 2017). Gelişen gida endüstrisi ve teknolojisi ile birlikte bilimsel araştırmalar sonucunda, zeytin ağac1 yan ürünlerinin farklı formlarda/şekillerde gıda endüstrisinin çeşitli alanlarında gıda formülasyonlarına dâhil edilerek insan beslenmesinde de kullanım potansiyeli olduğu görülmektedir.

Zeytin ağac1 yan ürünlerinin ana biyoaktif bileşikleri ile gıda endüstrisinde potansiyel teknolojik fonksiyonları Çizelge 1'de özet olarak verilmiştir. Buna göre, sadece zeytin yaprağının değil diğer zeytin yan ürünlerinin de biyoaktif bileşiklerce zengin olduğu ve gida endüstrisinde kullanım potansiyellerinin olduğu görülmektedir. Teknolojik olarak, zeytin yaprağının daha çok antioksidan ve antimikrobiyel özelliklerinden faydalanılmaktadır (Nunes vd., 2016). Zeytin yaprağının gıda endüstrisinde kullanım alanları ve uygulamalarına ait bazı araştırma sonuçları özet olarak Çizelge 2'de verilmiştir. Çizelgeden, zeytin yaprağının gıda endüstrisinde oldukça geniş bir kullanım alanına sahip olduğu görülmektedir. Yapılan çalışmalarda, zeytin yaprağının genel olarak gidalarda; antioksidan ve biyoaktif bileşiklerce zenginleştirme yapmak, oksidasyon stabilitesini artırarak raf ömrünü uzatmak ve fonksiyonel yeni ürünler üretmek gibi amaçlarla kullanıldığ1 görülmektedir. Araştırma sonuçlarından; zeytin yaprağının, belirlenen amaçlara ve teknolojik özelliklere ulaşılması bakımından, kayda değer bir potansiyel taşıdığı ve gida formülasyonlarinda rahatlikla kullanılabildiği/kullanılabileceği sonucu çıkarılabilir. Ayrıca zeytin yaprağının; bitkisel çay, g1da takviyesi, kurutulmuş yaprak (bütün ve ögütülmüş), ekstrakt ve tablet şeklinde ticari ürünleri tüm dünyada mevcuttur (Özcan ve Matthäus, 2017; Romani vd., 2019; Arslan vd., 2021). 
Çizelge 1. Zeytin ağacı yan ürünlerinin ana biyoaktif bileşikleri ile gıda endüstrisinde potansiyel teknolojik fonksiyonları

\begin{tabular}{|c|c|c|}
\hline Zeytin yan ürünleri & Biyoaktif bileşikler & Teknolojik ve fonksiyonel etkiler \\
\hline Zeytin posas 1 & $\begin{array}{l}\text { Fenolik bileşikler, Pektik } \\
\text { polisakkaritler, } \\
\text { Lignoselülozik lifler }\end{array}$ & $\begin{array}{l}\text { Fenolik bileşiklerin kapsüllenmesi, } \\
\text { Antioksidan özellikler, Jelleştirici ve } \\
\text { stabilize edici maddeler, Yağ ikamesi, G1da } \\
\text { ambalaj1 için biyokompozitler, Şeker } \\
\text { kaynağ1, Gida zenginleştirme }\end{array}$ \\
\hline Zeytin yaprağ1 & Fenolik bileşikler & $\begin{array}{l}\text { Gida ambalaj1 için biyolojik olarak } \\
\text { parçalanabilen filmler, Antimikrobiyel } \\
\text { özellikler, Antioksidan özellikler }\end{array}$ \\
\hline Zeytin değirmeni atık suları & $\begin{array}{l}\text { Fenolik bileşikler, Pektik } \\
\text { polisakkaritler }\end{array}$ & $\begin{array}{l}\text { Emülsifiye edici özellikler, Yağ tutma } \\
\text { özelliği, Stabilize edici maddeler, Gıda } \\
\text { zenginleştirme }\end{array}$ \\
\hline Zeytin çekirdeği & $\begin{array}{l}\text { Fenolik bileşikler, } \\
\text { Hemiselüloz, Selüloz, Lignin, } \\
\text { Biyoaktif peptitler }\end{array}$ & $\begin{array}{l}\text { Jelleştirici maddeler, Emülsifiye edici } \\
\text { özellikler, Kıvam artırıcı, Disperse edici } \\
\text { ajanlar, Antioksidan özellikler, Şeker-alkol } \\
\text { üretimi (ksilitol), Şeker kaynağ1, G1da } \\
\text { zenginleştirme }\end{array}$ \\
\hline
\end{tabular}

Nunes vd. (2016)

Çizelge 2. Zeytin yaprağının gıda endüstrisinde bazı kullanım alanları ve uygulamaları

\begin{tabular}{|c|c|c|c|c|}
\hline Gida grubu & Gıda ürünü & $\begin{array}{l}\text { Uygulama ve } \\
\text { konsantrasyon }\end{array}$ & Genel etkiler & $\mathrm{R}$ \\
\hline \multirow{5}{*}{ Süt ve ürünleri } & Pastörize süt & $\begin{array}{l}\% 1, \quad 2 \text { ve } 5 \text { yaprak } \\
\text { ekstraktı }\end{array}$ & $\begin{array}{l}\text { Fonksiyonel ve raf ömrü uzatılmış ürün } \\
\text { elde edilmesi }\end{array}$ & 1 \\
\hline & $\begin{array}{l}\text { Probiyotik süt } \\
\text { ve yoğurt }\end{array}$ & $\begin{array}{l}\% 0.2,0.4 \text { ve } 0.6 \text { yaprak } \\
\text { ekstraktı }\end{array}$ & $\begin{array}{l}\text { Lactobacillus acidophilus ve Bifidobacterium } \\
\text { bifidum'un büyümesi ve canlllı̆̆ını } \\
\text { artırma }\end{array}$ & 2 \\
\hline & Meyveli yoğurt & $\begin{array}{l}\% 0.1,0.2 \text { ve } 0.4 \text { yaprak } \\
\text { ekstraktı }\end{array}$ & $\begin{array}{l}\text { Antioksidan ve mineraller açısından } \\
\text { zenginleştirilmiş fonksiyonel ürün elde } \\
\text { edilmesi }\end{array}$ & 3 \\
\hline & Yoğurt & $\begin{array}{l}\% 1, \quad 2 \text { ve } 4 \text { yaprak } \\
\text { ekstraktı }\end{array}$ & $\begin{array}{l}\text { Antioksidan kapasitesi artırılmış ve } \\
\text { duyusal özellikleri geliştirilmiş ürün } \\
\text { elde edilmesi }\end{array}$ & 4 \\
\hline & Kefir & $\begin{array}{l}\% 0.10, \quad 0.15 \text { ve } 0.35 \\
\text { yaprak ekstrakt1 }\end{array}$ & $\begin{array}{l}\text { Antioksidan kapasitesi artırılmış } \\
\text { fonksiyonel ürün elde edilmesi }\end{array}$ & 5 \\
\hline \multirow{6}{*}{ Et ve ürünleri } & Köfte & $\begin{array}{l}\% 0.5, \quad 1, \quad 1.5 \text { ve } 2 \\
\text { öğütülmüş kuru yaprak }\end{array}$ & $\begin{array}{l}\text { Depolama stabilitesi artırılmış ürün } \\
\text { eldesi }\end{array}$ & 6 \\
\hline & Kuzu eti & $\begin{array}{l}\text { Biyo-film bileşiminde, } \\
\text { \%62.5 öğ̈üülmüş kuru } \\
\text { yaprak }\end{array}$ & $\begin{array}{l}\text { Aktif ambalaj olarak kullanıma } \\
\text { uygunluk ve raf ömrü artırılmış ürün } \\
\text { eldesi }\end{array}$ & 7 \\
\hline & Sığır kuşbaşı eti & $\begin{array}{l}\% 1,2 \text { ve } 3 \text { yaprak } \\
\text { ekstrakt1 }\end{array}$ & $\begin{array}{l}\text { Mikrobiyolojik ve oksidatif stabilitesi } \\
\text { artırılmış ürün eldesi }\end{array}$ & 8 \\
\hline & Köfte & $\begin{array}{l}\text { \%0.1, } 0.2 \text { ve } 0.3 \text { yaprak } \\
\text { ekstraktı }\end{array}$ & $\begin{array}{l}\text { Doğal antioksidan kaynağı olarak } \\
\text { kullanılabilme }\end{array}$ & 9 \\
\hline & Tavuk eti & $\begin{array}{l}\% 0.25,0.50 \text { ve } 1 \text { yaprak } \\
\text { ekstraktı }\end{array}$ & $\begin{array}{l}\text { Doğal antioksidan ve antimikrobiyel } \\
\text { kaynağı olarak kullanılabilme }\end{array}$ & 10 \\
\hline & Köfte & $\% 0.05$ yaprak ekstrakt1 & $\begin{array}{l}\text { Duyusal özellikleri geliştirilmiş ürün ve } \\
\text { antimikrobiyel kaynağ1 olarak } \\
\text { kullanılabilme }\end{array}$ & 11 \\
\hline
\end{tabular}


Çizelge 2. devam

\begin{tabular}{|c|c|c|c|c|}
\hline Gida grubu & Gida ürünü & $\begin{array}{l}\text { Uygulama ve } \\
\text { konsantrasyon }\end{array}$ & Genel etkiler & $\mathrm{R}$ \\
\hline \multirow{6}{*}{$\begin{array}{l}\text { Meyve, sebze } \\
\text { ve ürünleri/ } \\
\text { İçecekler/ } \\
\text { Soslar }\end{array}$} & Meyveli içecek & $\begin{array}{l}5,10,15,20 \text { ve } 25 \mathrm{mg} / 100 \\
\text { g yaprak ekstraktı }\end{array}$ & Fonksiyonel içecek eldesi & 12 \\
\hline & Sebze ezmesi & $\begin{array}{l}0.5 \text { ve } 1 \mathrm{~g} / \mathrm{kg} \text { yaprak } \\
\text { ekstraktı }\end{array}$ & $\begin{array}{l}\text { Duyusal özellikleri geliştirilmiş ve } \\
\text { depolama stabilitesi artırılmış ürün } \\
\text { eldesi }\end{array}$ & 13 \\
\hline & Kombucha çayı & $\begin{array}{l}\% 1,2.5 \text { ve } 5 \text { öğütülmüş } \\
\text { kuru yaprak }\end{array}$ & $\begin{array}{l}\text { Antioksidan kapasitesi artırılmış } \\
\text { fonksiyonel içecek eldesi }\end{array}$ & 14 \\
\hline & Bitki çay1 & $\begin{array}{l}\text { \%2 ögüüülmüş kuru yaprak } \\
\text { (infüzyon) }\end{array}$ & Fonksiyonel yeni ürün eldesi & 15 \\
\hline & Soğuk çay & $\begin{array}{llll}\% 0.10 \text { ve } & 0.15 & \text { yaprak } \\
\text { ekstrakt1 } & & \\
\end{array}$ & $\begin{array}{l}\text { Antioksidan kapasitesi } \\
\text { fonksiyonel içecek eldesi }\end{array}$ & 16 \\
\hline & Salça & $\begin{array}{l}500 \text { ve } 1000 \mathrm{mg} / \mathrm{kg} \text { yaprak } \\
\text { ekstrakt1 }\end{array}$ & $\begin{array}{l}\text { Aspergillus flavus'a karşı antifungal etki } \\
\text { ve raf ömrü uzatılmış ürün eldesi }\end{array}$ & 17 \\
\hline \multirow{2}{*}{$\begin{array}{l}\text { Hububat } \\
\text { ürünleri }\end{array}$} & Ekmek & $\% 5$ ve 10 yaprak ekstraktı & 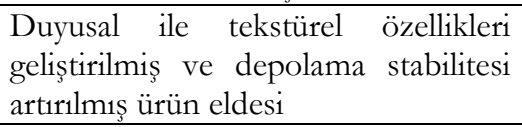 & 18 \\
\hline & $\begin{array}{l}\text { Atıştırmalık } \\
\text { ekmek çubuklar1 }\end{array}$ & $\begin{array}{l}400 \quad \mathrm{mg} / \mathrm{kg} \quad \text { yaprak } \\
\text { ekstrakt1 }\end{array}$ & $\begin{array}{l}\text { Fonksiyonel ve duyusal özellikleri } \\
\text { geliştirilmiş ürün eldesi }\end{array}$ & 19 \\
\hline \multirow{3}{*}{$\begin{array}{l}\text { Yemeklik } \\
\text { yağlar }\end{array}$} & Soya yağ1 & $\begin{array}{l}100,200 \text { ve } 300 \mathrm{mg} / \mathrm{kg} \\
\text { yaprak ekstrakt1 }\end{array}$ & $\begin{array}{l}\text { Oksidatif stabilitesi artırılmış ürün } \\
\text { eldesi }\end{array}$ & 20 \\
\hline & Zeytinyağ1 & $\% 2$ ve 4 yaprak & $\begin{array}{l}\text { Oksidatif stabilitesi artırılmış ürün } \\
\text { eldesi }\end{array}$ & 21 \\
\hline & Zeytinyağ1 & $\% 3$ yaprak & $\begin{array}{l}\text { Oksidatif stabilitesi artırilmış ve } \\
\text { besleyici özelliği geliş̧tirilmiş ürün } \\
\text { eldesi }\end{array}$ & 22 \\
\hline
\end{tabular}

R: Referanslar; 1: Palmeri vd. (2019), 2: Marhamatizadeh vd. (2013), 3: Peker ve Arslan (2016), 4: Won-Young vd. (2020), 5: Okur (2021), 6: Acar (2018), 7: Martiny vd. (2020), 8: Aytul vd. (2004), 9: Rubel vd. (2021), 10: Saleh vd. (2020), 11: Kolcuoğlu ve Halkman (2021), 12: Kranz vd. (2010), 13: Difonzo vd. (2019), 14: Değirmencioğlu vd. (2020), 15: Işık (2017), 16: Arslan vd. (2021), 17: Jafari vd. (2017), 18: Moghaddam vd. (2020), 19: Difonzo vd. (2018), 20: Mohammadi vd. (2016), 21: Doğru (2019), 22: Tarchoune vd. (2019).

\section{SONUÇ VE ÖNERILLER}

Günümüzde, insanların yaşam tarzlarındaki değişiklikler ile birlikte çeşitli faktörler (bilinçlenme, sağlıklı beslenme üzerine yapılan açıklamalar, bilimsel gelişmeler, sentetik katk1 maddelerine duyulan şüphe ve doğal kaynaklara artan ilgi vb.) tüketicilerin sağlık, beslenme ve refah anlayışlarında değişime neden olmuştur/olmaktadır. Bu nedenle, "fonksiyonel ürün" ve konuyla ilgili araştırmalara ilgi/talep her geçen gün artmaktadır. Fonksiyonel gida kavramıyla ilişkili olarak, biyoaktif bileşiklerce zengin ve fitokimyasal profilleri belirlenmiş olan tıbbi ve aromatik bitkiler oldukça önemlidir. Bu nedenle akılc1 ve sürdürülebilir çözümler aramaya yönelen araştırmacılar, biyoaktif bileşiklerce zengin ve atık durumunda olan tarımsal yan ürünlerin gidalarda değerlendirilmesi üzerine odaklanmıştır. Bunlardan önemli biri de tarımsal bir yan ürün olan ve fitokimyasal içeriğiyle dikkat çeken zeytin yaprağıdır. Zeytin yaprağ1 üzerine yapılan literatür okumaları sonucunda; antioksidan ve fenolik bileşikler bakımından oldukça zengin olduğu, bileşimlerindeki fitokimyasallar sayesinde pek çok terapötik etkiye sahip olduğu ve gida uygulamalarında kullanım potansiyellerinin olduğu görülmüştür. Zeytin yaprağını değerlendirmek, hem fonksiyonel özellikleri geliştirilmiş ürünler elde etmeye hem de atık sorunlarını çözmeye katkı sağlayarak katma değer oluşturacaktır. Bu nedenlerle, zeytin yaprağının gıda endüstrisindeki uygulamaları artırılabilir/çeşitlendirilebilir. Ayrıca zeytin yaprağının veya benzer özellikteki bitkilerin gıda ortamındaki etkilerinin de histolojik ve toksikolojik değerlendirmeler ile kontrol edilmesi 
büyük önem taşımakta ve bu alanda multidisipliner çalışmaların yapılması gerekmektedir.

\section{ÇIKAR ÇATIŞMASI BEYANI}

Yazarlar, bu derleme makalesiyle ilgili olarak başka kişiler ve/veya kurumlar arasında çıkar çatışması olmadığını beyan etmektedir.

\section{YAZAR KATKILARI}

Yazarlar makalenin yazımına eşit oranda katk1 yapmışlar ve makalenin yayın aşamasındaki süreçte gerekli kontrolleri yapıp son halini onaylamışlardır.

\section{KAYNAKLAR}

Acar, G. (2018). Sığır eti köftelerinin depolama stabilitesi üzerine farklı oranlarda zeytin yaprağ ilavesinin etkisi. Selçuk Üniversitesi Fen Bilimleri Enstitüsü Gıda Mühendisliği Anabilim Dalı Yüksek Lisans Tezi, Konya, Türkiye, 33 s.

Arslan, E.E., Karademir, G., Berktaş, S., Çam, M. (2021). Zeytin yaprağ1 ekstraktı içeren soğuk çay üretimi. Mühendislik Bilimleri ve Tasarm Dergisi, 9(3): 843-849. doi:10.21923/jesd.904344.

Aytul, K.K., Korel, F., Arserim-Uçar, D.K., Uysal, I., Bayraktar, O. (2004). Efficacy of olive leaf extract for enhancing quality of beef cubes. In proceedings of the 54 th International Congress of meat science and technology. (pp. 51) South Africa: Cape Town, 51.

Blasi, F., Urbani, E., Simonetti, M.S., Chiesi, C., Cossignani, L. (2016). Seasonal variations in antioxidant compounds of Olea europaea leaves collected from different Italian cultivars. J Appl Bot Food Qual, 89: 202-207. doi: 10.5073/ JABFQ.2016.089.025.

Boudhrioua, N., Bahloul, N., Ben Slimen, I., Kechaou, N. (2009). Comparison on the total phenol contents and the color of fresh and infrared dried olive leaves. Ind Crops Prod, 29(2-3): 412-419. doi: 10.1016/j.indcrop.2008.08.001.

Brahmi, F., Mechri, B., Dhibi, M., Hammami, M. (2013). Variations in phenolic compounds and antiradical scavenging activityof Olea europaea leaves and fruits extracts collected in two different seasons. Ind Crops Prod, 49: 256-264. doi: 10.1080/10412905.2016.1166157.

Carvalho, M., Ferreira, P.J, Mendes, V.S., Silva, R., Pereira, J.A, Jerónimo, C., Silva, B.M. (2010). Human cancer cell antiproliferative and antioxidant activities of Juglans regia L. Food Chem Toxicol, 48(1): 441-447. doi: 10.1016/j.fct.2009.10.043.

de Bock, M., Derraik, J.G.B., Brennan, C.M., Biggs, J.B, Morgan, P.E, Hodgkinson, S.C., Hofman, P.L., Cutfield, W.S. (2013). Olive (Olea europaea L.) leaf polyphenols improve insulin sensitivity in middle-aged overweight men: A randomized, Placebo-Controlled, Crossover Trial. Plos One, 8(3): e57622, 1-8. doi: 10.1371/journal.pone.0057622.

Değirmencioğlu, N., Yildiz, E., Guldas, M., Gurbuz, O. (2020). Health benefits of kombucha tea enriched with olive leaf and honey. $J$ Obes Chronic Dis, 4(1): 1-5. doi:10.17756/jocd.2020031.

Difonzo, G., Pasqualone, A., Silletti, R., Cosmai, L., Summo, C., Paradiso, V.M, Caponio, F. (2018). Use of olive leaf extract to reduce lipid oxidation of baked snacks. Food Res Int, 108: 4856. doi: 10.1016/j.foodres.2018.03.034.

Difonzo, G., Squeo, G., Calasso, M., Pasqualone, A., Caponio, F. (2019). Physico-chemical, microbiological and sensory evaluation of readyto-use vegetable pâté added with olive leaf extract. Foods, 8(4): 138, 1-12. doi: $10.3390 /$ foods 8040138 .

Doğru, E. (2019). Zeytin yaprağı ilavesi ile Ayvalık çeşidi zeytin meyvesinden üretilen natürel zeytinyağının oksidatif stabilitesinin belirlenmesi. Harran Üniversitesi Fen Bilimleri Enstitüsü Gıda Mühendisliği Anabilim Dalı Yüksek Lisans Tezi, Şanliurfa, Türkiye, $40 \mathrm{~s}$.

Ekren, S., Yerlikaya, O., Tokul, H.E., Akpınar, A., Açu, M. (2013). Chemical composition, antimicrobial activity and antioxidant capacity of some medicinal and aromatic plant extracts. Afr J Microbiol Res, 7(5): 383-388. doi: 10.5897/AJMR12.1765. 
El, S.N., Karakaya, S. (2009). Olive tree (Olea europaea) leaves: Potential beneficial effects on human health. Nutr Rev, 67(11): 632-638. doi: 10.1111/j.1753-4887.2009.00248.x.

Espeso, J., Isaza, A., Lee, J.Y., Sörensen, P.M., Jurado, P., Avena-Bustillos, R.J, Olaizola, M., Arboleya, J.C. (2021). Olive leaf waste management. Front Sustain Food Syst, 5: 1-13. doi: 10.3389/fsufs.2021.660582.

Gahukar, R.T. (2018). Management of pests and diseases of important tropical/subtropical medicinal and aromatic plants: A review. J Appl Res Med Aromat Plants, 9: 1-18. doi: 10.1016/j.jarmap.2018.03.002.

Gıda ve Tarım Örgütü (FAO), (2019). Bitkisel Üretim İstatistikleri, http: //www. fao.org/ faostat/en/\#data/QCL (Erişim Tarihi: 10.10.2021).

Güler, O., Polat, R., Karaköse, M., Çakıloğlu, U., Akbulut, S. (2021). An ethnoveterinary study on plants used for the treatment of livestock diseases in the province of Giresun (Turkey). S Afr J Bot, 142: 53-62. doi: 10.1016/j.sajb.2021.06.003.

Gür, F., Ağgül, A.G., Gülaboğlu, M. (2020). Su ile hazırlanan zeytin yaprağ1 özütünün ratlarda streptozotosin kaynaklı oksidatif stres ve lipit peroksidasyonu üzerine etkileri. Iğdır Üniversitesi Fen Bilimleri Enstitüsü Dergisi, 10(4): 2406-2415. doi: $10.21597 /$ jist. 784425 .

Heilman, J., Anyangwe, N., Tran, N., Edwards, J., Beilstein, P., López, J. (2015). Toxicological evaluation of an olive extract, H35: Subchronic toxicity in the rat. Food Chem Toxicol, 84: 18-28. doi: 10.1016/j.fct.2015.07.007.

Iş1k, E. (2017). Farklı yöntemlerle kurutulan zeytin yaprağından üretilen bitki çayının biyoaktif bileşenleri, antioksidan kapasitesi ve duyusal beğenisi. Çanakkale Onsekiz Mart Üniversitesi Fen Bilimleri Enstitüsü Gıda Mühendisliği Anabilim Dalı Yüksek Lisans Tezi, Çanakkale, Türkiye, $63 \mathrm{~s}$.

Jafari, S.M., Ghanbari, V., Dehnad, D., Ganje, M. (2017). Neural networks modeling of Aspergillus flavus growth in tomato paste containing microencapsulated olive leaf extract. J Food Saf, 38:1 2396, 1-10. doi: 10.1111/jfs.12396.

Jemai, H., El Feki, A., Sayadi, S. (2009). Antidiabetic and antioxidant effects of hydroxytyrosol and oleuropein from olive leaves in alloxan-diabetic rats. J Agric Food Chem, 57(19): 8798-8804. doi: 10.1021/jf901280r.

Kadioğlu, B., Kadıŏ̆lu, S. (2021). Medicinal and aromatic plants consumption habits of consumers in the coronavirus pandemic. Atatüre Univ J Agricultural Faculty, 52(3): 325-334. doi: 10.17097/ataunizfd.860913.

Khan, M.Y., Panchal, S., Vyas, N., Butani, A., Kumar, V. (2007). Olea europaea: A phytopharmacological review. Pharmacogn Rev, 1(1): 114118.

Kiani, S., Minaei, S., Ghasemi-Varnamkhasti, M. (2016). Application of electronic nose systems for assessing quality of medicinal and aromatic plant products: A review. J Appl Res Med Aromat Plants, 3(1): 1-9. doi:10.1016/j.jarmap.2015.12.002.

Kolcuoğlu, G., Halkman, A.K. (2021). Çeşitli bitkisel ekstraktlar ve kombinasyonlarının köftede antimikrobiyel etkisinin araştırılması. Gıda, 46(5), 1092-1104. doi: 10.15237 / gida.GD21084.

Kranz, P., Braun, N., Schulze, N., Kunz, B. (2010). Sensory quality of functional beverages: Bitterness perception and bitter masking of olive leaf extract fortified fruit smoothies. J Food Sci, 75(6): 308-311. doi: 10.1111/j.17503841.2010.01698.x.

Lubbe, A., Verpoorte, R. (2011). Cultivation of medicinal and aromatic plants for specialty industrial materials. Ind Crops Prod, 34(1): 785-801. doi: 10.1016/j.indcrop.2011.01.019.

Marhamatizadeh, M.H., Ehsandoost, E., Gholami, P., Mohaghegh, M.D. (2013). Effect of olive leaf extract on growth and viability of Lactobacillus acidophilus and Bifidobacterium bifidum for production of probiotic milk and yoghurt. Intl J Farm end Alli Sci, 2(17): 572-578. doi: 10.3923/pjn.2010.787.793.

Markhali, F.S., Teixeira, J.A., Rocha, C.M.R. (2020). Olive tree leaves-a source of valuable 
active compounds. Processes, 8: 1177, 1-18. doi:10.3390/pr8091177.

Martiny, T.R., Raghavan, V., Moraes, C.C., Rosa, G.S.D., Dotto, G.L. (2020). Bio-based active packaging: Carrageenan film with olive leaf extract for lamb meat preservation. Foods, 9(12): 1759, 1-14. doi: 10.3390/foods9121759.

Moghaddam, M.F.Z., Jalali, H., Nafchi, A.M., Nouri, L. (2020). Evaluating the effects of lactic acid bacteria and olive leaf extract on the quality of gluten-free bread. Gene Rep, 21: 100771. doi: 10.1016/j.genrep.2020.100771.

Mohammadi, A., Jafari, S.M., Esfanjani, A.F., Akhavan, S. (2016). Application of nanoencapsulated olive leaf extract in controlling the oxidative stability of soybean oil. Food Chem, 190: 513-519. doi: 10.1016/j.foodchem.2015.05.115.

Nicoli, F., Negro, C., Vergine, M., Aprile, A., Nutricati, E., Sabella, E., Miceli, A., Luvisi, A., De Bellis, L. (2019). Evaluation of phytochemical and antioxidant properties of 15 Italian Olea europaea L. cultivar leaves. Molecules, 24(10): 1998, 1-12. doi: 10.3390/molecules24101998.

Nunes, M.A., Pimentel, F.B., Costa, A.S., Alves, R.C., Oliveira, M.B. (2016). Olive by-products for functional and food applications: Challenging opportunities to face environmental constraints. Innov Food Sci Emerg Tecbnol, 35: 139148. doi: 10.1016/j.ifset.2016.04.016.

Okur, Ö.D. (2021). An evaluation of the quality characteristics of kefir fortified with olive (Olea europaea) leaf extract. Br Food J, doi: 10.1108/BFJ07-2021-072.

Özcan, M.M., Matthäus, B. (2017). A review: Benefit and bioactive properties of olive (Olea europaea L.) leaves. Eur Food Res Technol, 243: 8999. doi: 0.1007/s00217-016-2726-9.

Palmeri, R., Parafati, L., Trippa, D., Siracusa, L., Arena, E., Restuccia, C., Fallico, B. (2019). Addition of olive leaf extract (OLE) for producing fortified fresh pasteurized milk with an extended shelf life. Antioxidants, 8(8): 255, 1-14. doi: 10.3390/antiox8080255.

Papachristodoulou, A., Tsoukala, M., Benaki, D., Kostidis, S., Gioti, K., Aligiannis, N., Pratsinis,
H., Kletsas, D., Skaltsounis, A., Mikros, E., Tenta, R. (2016). Oleuropein is a powerful sensitizer of doxorubicin-mediated killing of prostate cancer cells and exerts its action via induction of autophagy. J Cancer Res Treat, 4(4): 61-68. doi: 0.12691/jcrt-4-4-2.

Peker, H., Arslan, S. (2016). Effect of olive leaf extract on the quality of low fat apricot yogurt. $J$ Food Process Preserv, 41: e13107, 1-10. doi: 10.1111/jfpp.13107.

Pereira, A.P., Ferreira, I.C., Marcelino, F., Valentão, P., Andrade, P.B., Seabra, R., Estevinho, L., Bento, A., Pereira, J.A. (2007). Phenolic compounds and antimicrobial activity of olive (Olea europaea L. Cv. Cobrançosa) leaves. Molecules, 12(5): 1153-1162. doi: 10.3390/12051153.

Perrinjaquet-Moccetti, T., Busjahn, A., Schmidlin, C., Schmidt, A, Bradl, B., Aydogan, C. (2008). Food supplementation with an olive (Olea europaea L.) leaf extract reduces blood pressure in borderline hypertensive monozygotic twins. Phytother Res, 22(9): 1239-1242. doi: 10.1002/ptr.2455.

Polat, R. (2019). Ethnobotanical study on medicinal plants in Bingol (City center) (Turkey). J Herb Med, 16: 100211. doi: 10.1016/ j.hermed.2018.01.007.

Prasathkumar, M., Anisha, S., Dhrisya, C., Becky, R. (2021). Therapeutic and pharmacological efficacy of selective Indian medicinal plants-A review. Phytomedicine Plus, 1(2): 100029. doi: 10.1016/j.phyplu.2021.100029.

Rahmanian, N., Jafari, S.M., Wani, T.A. (2015). Bioactive profile, dehydration, extraction and application of the bioactive components of olive leaves. Trends Food Sci Technol, 42: 150-172. doi:10.1016/j.tifs.2014.12.009.

Ravanbakhsh, A., Mahdavi, M., Jalilzade-Amin, G., Javadi, S., Maham, M., Mohammadnejad, D., Rashidi, M.R. (2016). Acute and subchronic toxicity study of the median septum of Juglans regia in wistar rats. Adv Pharm Bull, 6(4): 541-549. doi: 10.15171/apb.2016.068. 
Romani, A., Ieri, F., Urciuoli, S., Noce, A., Marrone, G., Nediani, C., Bernini., R. (2019). Health effects of phenolic compounds found in extra-virgin olive oil, by-products, and leaf of Olea europaea L. Nutrients, 11(8): 1776, 1-33. doi: 10.3390/nu11081776.

Rubel, S.A., Yu, Z.N., Murshed, H.M., Ariful Islam, S.M., Sultana, D., Rahman, S.M.E., Wang, J. (2021). Addition of olive (Olea europaea) leaf extract as a source of natural antioxidant in mutton meatball stored at refrigeration temperature. J Food Sci Technol, 58(10): 4002-4010. doi: 10.1007/s13197-020-04863-y.

Ruzzolini, J., Peppicelli, S., Andreucci, E., Bianchini, F., Scardigli, A., Romani, A., la Marca, G., Nediani, C., Calorini, L. (2018). Oleuropein, the main polyphenol of olea europaea leaf extract, has an anti-cancer effect on human BRAF melanoma cells and potentiates the cytotoxicity of current chemotherapies. Nutrients, 10(12): 1950, 1-17. doi: 10.3390/nu10121950.

Salah, M.B., Abdelmelek, H., Abderraba, M. (2012). Study of phenolic composition and biological activities assessment of olive leaves from different varieties grown in Tunisia. Med Chem, 2(5): 107-111. doi: 10.4172/21610444.1000124.

Saleh, E., Morshdy, A.E., El-Manakhly, E., AlRashed, S.F., Hetta, H., Jeandet, P., Yahia, R., ElSaber Batiha, G., Ali, E. (2020). Effects of olive leaf extracts as natural preservative on retailed poultry meat quality. Foods, 9(8): 1017, 1-12. doi: 10.3390/foods 9081017 .

Sevim, D., Tuncay, Ö. (2012). Ayvalık ve memecik zeytin çeşitlerinin yaprağı ve meyvelerinin toplam fenolik madde miktarı ve antioksidan aktiviteleri. Grda, 37 (4): 219-226.

Souilem, S., Fki, I., Kobayashi, I., Khalid, N., Neves, M.A., Isoda, H., Sayadi, S., Nakajima, M. (2017). Emerging technologies for recovery of value-added components from olive leaves and their applications in food/feed industries. Food Bioproc Tech, 10, 229-248. doi: 10.1007/s11947016-1834-7.
Sudjana, A.N., D'Orazio, C., Ryan, V., Rasool, N., Ng, J., Islam, N., Riley, T.V., Hammer, K.A. (2009). Antimicrobial activity of commercial Olea europaea (olive) leaf extract. Int J Antimicrob Agents, 33(5): 461-463. doi: 10.1016/j.ijantimicag. 2008.10.026.

Susalit, E., Agus, N., Effendi, I., Tjandrawinata, R.R., Nofiarny, D., Perrinjaquet-Moccetti, T., Verbruggen, M. (2011). Olive (Olea europaea) leaf extract effective in patients with stage-1 hypertension: comparison with captopril. Phytomedicine, 18(4): 251-258. doi: 10.1016/ j.phymed.2010.08.016.

Tarchoune, I., Sgherri, C., Eddouzi, J., Zinnai, A., Quartacci, M. F., Zarrouk, M. (2019). Olive leaf addition increases olive oil nutraceutical properties. Molecules, 24(3): 545, 1-15. doi: 10.3390/molecules24030545.

Thakur, M., Kumar, R. (2021). Microclimatic buffering on medicinal and aromatic plants: A review. Ind Crops Prod, 160: 113144. doi: 10.1016/j.indcrop.2020.113144.

Türkiye İstatistik Kurumu (TÜIK), (2019). Bitkisel Üretim İstatistikleri, https://data.tuik.gov.tr/Bulten/Index?p=Bitkise 1-Uretim-Istatistikleri-2019-30685 (Erişim Tarihi: 10.10.2021).

Uylaşer, V., Yıldız, G. (2014). The historical development and nutritional importance of olive and olive oil constituted an important part of the mediterranean diet. Crit Rev Food Sci Nutr, 54(8): 1092-1101. doi: 10.1080/10408398.2011.626874.

Wainstein, J., Ganz, T., Boaz, M., Bar Dayan, Y., Dolev, E., Kerem, Z., Madar, Z. (2012). Olive leaf extract as a hypoglycemic agent in both human diabetic subjects and in rats. $J$ Med Food, 15(7): 605-610. doi: 10.1089/jmf.2011.0243.

Won-Young, C., Da-Hee, K., Ha-Jung, L., SuJung, Yeon., Chi-Ho, Lee. (2020). Quality characteristic and antioxidant activity of yogurt containing olive leaf hot water extract. CyTA J Food, 18(1): 43-50. doi: 10.1080/19476337.2019.1640797. 